\title{
Methylmercury transport and fate shows strong seasonal and spatial variability along a high Arctic freshwater hydrologic continuum
}

Varty, Stephanie $^{1}$; Lehnherr, Igor ${ }^{1}$; St. Pierre, Kyra ${ }^{2}$; Kirk, Jane³ ${ }^{3}$ Wisniewski, Victoria ${ }^{1}$

${ }^{1}$ Department of Geography, Geomatics and Environment, University of Toronto Mississauga, Mississauga ON L5L 1C6, Canada

2Department of Biological Sciences, University of Alberta, Edmonton, Alberta T6G 2E3, Canada

${ }^{3}$ Canada Centre for Inland Waters, Environment and Climate Change Canada, Burlington ON L7S 1A1, Canada

Corresponding author: igor.lehnherr@utoronto.ca

This supporting information document is 27 pages long and includes supplementary methods, and results and discussion, as well as 11 additional figures and 9 tables. 


\section{List of Supplementary Figures}

Figure S1. Surface water concentrations of Hg species in the Skeleton Continuum throughout the 2015 open water summer season.

Figure S2. Surface water concentrations of Hg species in the Skeleton Continuum throughout the 2016 open water summer season.

Figure S3. \% $\mathrm{MeHg}_{\mathrm{T}}$ in Skeleton Continuum surface water throughout the summers of 2015 and 2016.

Figure S4. Concentrations of $\mathrm{THg}_{\mathrm{T}}, \mathrm{MeHg}_{\mathrm{T}}$, and $\% \mathrm{MeHg}_{\mathrm{T}}$ at different depths in the Skeleton Lake water column during spring and summer.

Figure S5. \% MeHg and $\mathrm{Hg}$ methylation potential $\left(k_{m}, \% \mathrm{~d}^{-1}\right)$ in Skeleton Lake sediment during the summer (open water) and spring (ice-covered) seasons.

Figure S6. Potential rate constants of $\mathrm{Hg}$ methylation and demethylation at various depths below the sediment-water interface in Skeleton Lake Sediments during the open water and ice-covered seasons.

Figure S7. Potental rates of $\mathrm{Hg}$ methylation and \% $\mathrm{MeHg}$ at various depths below the sediment-water interface in Skeleton Lake and Pond 11 sediments.

Figure S8. \%MeHg in different wetland soil horizons across a transect el moisture (coring sites A to G at the wetland mid-point, bars are stacked in the order of greatest to least soil saturation).

Figure S9. Potential rates of $\mathrm{Hg}$ methylation and demethylation, and \% $\mathrm{MeHg}$ in wetland soils.

Figure S10. Photos of the primary sampling sites in the Skeleton continuum.

Figure S11. Time-series of mercury methylation and demethylation in snow and snowmelt.

\section{List of Supplementary Tables}

Table S1. Incubation times and final stable isotope spike concentrations for methylation and demethylation incubation experiments in water, sediment/soil, snowpack, and snowmelt.

Table S2. Mean concentrations for various water chemistry parameters in Skeleton Lake.

Table S3. Cryoconcentration of solutes in Skeleton Lake as a result of lake ice formation.

Table S4. Skeleton Lake water column THg and MeHg pools in spring (under ice) and summer (open water).

Table S5. Zooplankton THg and MeHg pools in spring (under ice) and summer (open water).

Table S6. Potential methylation and demethylation rate constants, and \%MeHg at different depths within wetland soil profiles.

Table S7. Snow water equivalence, total and dissolved THg and MeHg concentrations, loadings, and $\% \mathrm{MeHg}$ in snowpacks within the Skeleton continuum.

Table S8. Methylation and demethylation constants in Skeleton continuum snow.

Table S9. Ranges of THg, MeHg, and methylation/demethylation constants) in all media sampled within the Skeleton continuum. 


\section{METHODS}

Sample Collection: Water samples were collected in pre-cleaned amber glass bottles by hand or using a peristaltic geo-pump equipped with a Teflon tubing sampling line. For each sampling site and time, a filtered and unfiltered sample was collected. Samples were filtered in the Lake Hazen Quttinirpaaq Field Laboratory using Nalgene MF75 series filterunits equipped with a $0.45 \mu \mathrm{m}$ cellulose nitrate membrane previously cleaned with a $1 \%$ $\mathrm{HCl}$ solution and rinsed with MilliQ water. ${ }^{1}$ The filtrate was then transferred into a clean amber glass bottles. All samples were acidified to $0.2 \%(\mathrm{v} / \mathrm{v})$ using trace-metal grade concentrated $\mathrm{HCl}$.

Bulk zooplankton samples were collected during full ice cover (May 30, 2017) and during the open water season (July 13, 17 and 21, 2016). A $15 \mathrm{~cm}$ diameter zooplankton net with $80 \mu \mathrm{m}$ mesh was used to perform a known number of $\sim 2 \mathrm{~m}$ vertical tows. Samples were collected from the centre of the lake, either using an inflatable rubber boat or through a hole in the ice, depending on the season. Samples were transferred into a whirlpack bag using a wash bottle filled with lake water.

Sediment samples were collected with a UWitec gravity corer, using the lake ice as a platform, or by hand from an inflatable boat when coring shallow ponds. Wetland soil samples were collected with a stainless-steel soil corer.

All snow, sediment, soil and zooplankton samples were frozen immediately after collection.

Methylation assays using enriched Hg stable isotope tracers: Potential Hg methylation rates were determined by the addition of a known amount of ${ }^{198} \mathrm{Hg}$ (II) (purity: 90.5\%) enriched stable isotope tracer to the sample for a set period of time to quantify the production of $\mathrm{Me}^{198} \mathrm{Hg}^{2}$ Potential MeHg demethylation was determined during the same incubations but was quantified by measuring the loss of added $\mathrm{Me}^{199} \mathrm{Hg}$ (purity: 91.9\%) over time. The amount of isotope added into each sample (Table S1) was based on previous data on $\mathrm{Hg}$ concentrations at this site; ${ }^{1-3}$ and selected so as to minimize the increase in $\mathrm{Hg}$ already present in the sample (e.g., tracer level additions whenever possible) while being 
large enough to allow for detection. The rates obtained from these assays are considered potential rates as the added tracers may have a different chemical speciation and/or sediment - porewater partitioning and may therefore be more reactive than ambient $\mathrm{Hg}(\mathrm{II})$ and MeHg. However, measuring potential rates is useful to compare Hg(II) methylation activity between sites and investigate factors that might control methylation. The methods used here were based on previously described methods for measuring methylation in sediment/soil, ${ }^{2}$ natural waters, ${ }^{4}$ and snow ${ }^{5}$ and are described in detail below.

\section{Sediment/Soil Methylation Assays:}

Intact sediment cores were collected by hand during the open water season from a small inflatable boat using $5 \mathrm{~cm}$ diameter Lexan core tubes with pre-drilled injections ports (equipped with silicone septa) distributed vertically at $0.5 \mathrm{~cm}$ intervals along the core. Cores were visually inspected to ensure the sediment-water interface was intact and stoppered to maintain redox gradients and preserve the sediment-water interface. Once all cores were collected, the overlying water was drawn down to $10 \mathrm{~cm}$ above the sedimentwater interface using a syringe and c-flex tubing. $100 \mu \mathrm{l}$ of the enriched stable isotope solution (diluted and pre-equilibrated with filtered site surface water) was injected every 1 $\mathrm{cm}$ in the sediment core in a fan like pattern using a $100 \mu$ l gas-tight syringe. Injections began at $1 \mathrm{~cm}$ above the sediment-water interface and ended at a depth of $4 \mathrm{~cm} .{ }^{2}$ Injections resulted in $77.88 \mathrm{ng}{ }^{198} \mathrm{Hg}$ and $0.257 \mathrm{ng} \mathrm{Me}{ }^{199} \mathrm{Hg}$ added into every $1 \mathrm{~cm}$ depth interval. One core from each set (i.e., from each unique site/date combination) was reserved as a blank, sectioned into $2 \mathrm{~cm}$ depth intervals, placed in whirlpack bags, amened with isotope tracer solution and frozen immediately. The remaining cores were incubated for 5 hours in a dark cooler filled with site water to maintain in situ temperature $\left(12 \pm 2{ }^{\circ} \mathrm{C}\right)$. After 5 hours, the remaining cores were extruded and sectioned into $2 \mathrm{~cm}$ intervals and frozen.

During the spring sampling period methylation assays were carried out as described above, with the following modifications. Sediment cores were collected with a UWitec gravity-corer through an augured hole in the lake ice. Sediment cores were carefully transported back to camp vertically to maintain the integrity and intact nature of the cores. 
These large diameter cores were then sub-sampled using the pre-drilled $5 \mathrm{~cm}$ diameter core tubes described above (i.e., the large cores were themselves cored using the smaller core tubes). The cores were then amended with enriched stable isotope tracers as described above and incubated in the dark at $2-4{ }^{\circ} \mathrm{C}$ to maintain in situ conditions.

Wetland soil cores were collected and incubated using a similar methodology as the sediment samples, with the minor difference that the cores had no overlying water and were injected with the stable isotope tracer solution at $1 \mathrm{~cm}$ intervals throughout the entire soil core profile, starting as close as possible to the top of the core. Soil cores were then placed back into the hole created by core extraction and left in the field to incubate for 5 hours, after which time they were sectioned into $2 \mathrm{~cm}$ depth intervals and frozen, with the exception of the blank cores which were treated as described above.

\section{Lake Water Methylation Assays:}

A peristaltic pump was used to collect lake water from different depths into pre-cleaned $250 \mathrm{ml}$ amber Boston Round bottles equipped with Teflon lined caps that had been predrilled to allow for injection of the enriched stable isotope tracer solution. To maintain in situ redox conditions, bottles were filled with their volume twice, and capped with no headspace. Samples were transported back to the field laboratory at camp in a cooler. In the field laboratory, $100 \mu \mathrm{l}$ of the enriched stable isotope tracer solution was injected into each bottle using a $100 \mu$ l gas tight syringe, bringing the final concentration of ${ }^{198} \mathrm{Hg}$ (II) and $\mathrm{Me}^{199} \mathrm{Hg}$ to $2.160 \mathrm{ng} \mathrm{L}^{-1}$ and $0.109 \mathrm{ng} \mathrm{L}^{-1}$, respectively. Sample bottles were kept in a dark cooler at in situ temperature. At time steps of 0, 6, 16 and 28 hours after injection, one bottle from each depth was acidified to $0.2 \%$ with trace metal grade concentrated hydrochloric acid ( $\mathrm{HCl})$.

\section{Snow and Snowmelt Methylation Assays:}

For the solid snow methylation assays, six snow cores (i.e., duplicate cores for each of three incubation time points) were collected at each sampling site using acid washed $7.3 \mathrm{~cm}$ ID polycarbonate core tubes with pre-drilled injection ports every $2 \mathrm{~cm}$ on both sides of the 
snow core (in alternating positions). Once transported back to the field laboratory, cores were injected with $100 \mu \mathrm{l}$ of the isotope solution in a fan-like pattern at each injection port covered by snow, using a $100 \mu$ l gas-tight syringe. Injections resulted in the addition of 0.13 ng and $0.00057 \mathrm{ng}$ of ${ }^{198} \mathrm{Hg}$ (II) and $\mathrm{Me}^{199} \mathrm{Hg}$ per $\mathrm{cm}$, respectively. Cores were then taken outside and incubated by placing them into the snowpack, making sure to line up the airsnow interface inside the core with the top of the snowpack. Cores were incubated for 0,24 and 48 hours. At each time point duplicate cores were sacrificed and each core was emptied into pre-cleaned $500 \mathrm{ml}$ glass jars and acidified to $0.5 \%$ with trace metal grade concentrated $\mathrm{HCl}$. The samples were then allowed to melt over the next couple of hours to ensure that the acid would become well mixed and halt any microbial activity within the sample.

For the snowmelt methylation assays, six samples (i.e., duplicates for each of three incubation time points) were collected at each sampling site using a pre-cleaned $5 \mathrm{~cm}$ ID stainless steel corer and spatula. Enough snow was collected to fill pre-cleaned $500 \mathrm{ml}$ glass jars and each jar was amended with ${ }^{198} \mathrm{Hg}(\mathrm{II})$ and $\mathrm{Me}^{199} \mathrm{Hg}$. Injections were performed to evenly distribute the spike within each snow sample and resulted in final concentrations of ${ }^{198} \mathrm{Hg}(\mathrm{II})$ and $\mathrm{Me}^{199} \mathrm{Hg}$ of $4.1 \mathrm{ng} \mathrm{L}^{-1}$ and $0.02 \mathrm{ng} \mathrm{L}^{-1}$ of ${ }^{198} \mathrm{Hg}(\mathrm{II})$ and $\mathrm{Me}^{199} \mathrm{Hg}$, respectively. Following the addition of the stable isotope spike, the samples were allowed to melt gradually to mimic snowmelt. At 0,24 , and 48 hours after injection, one of each duplicate was acidified to $0.5 \%$ trace metal grade concentrated $\mathrm{HCl}$. At 24 hours, samples were mostly melted, but with a small amount of floating snow in the jar, at 48 hours all snow had entirely melted.

Sample Analysis: Water samples for the spatiotemporal survey were analyzed for THg and $\mathrm{MeHg}$ at the Biogeochemical Analytical Service Laboratory (BASL), University of Alberta. Zooplankton and snow samples were analyzed at Environment and Climate Change Canada's Canadian Centre for Inland Waters (CCIW), and sediment, soil and methylation assay samples were analyzed at the University of Toronto. All solid phase samples were freeze-dried and homogenized prior to analysis. 
At both BASL and the University of Toronto, MeHg was measured using isotopedilution gas chromatography inductively-coupled mass spectrometry (ID-GC-ICP-MS). ${ }^{6}$ Prior to analysis, water and snow samples were distilled following US EPA Method 1630.7 $0.3 \mathrm{~g}$ of solid samples (+38.7g MilliQ water) or $40 \mathrm{~g}$ of liquid sample were amended with $500 \mu \mathrm{l} 9 \mathrm{M}$ sulphuric acid $\left(\mathrm{H}_{2} \mathrm{SO}_{4}\right), 200 \mu \mathrm{l} 20 \%$ potassium chloride $(\mathrm{KCl})$, and $1 \mathrm{ml}$ copper sulfate $\left(\mathrm{Cu}\left(\mathrm{SO}_{4}\right)\right)$ prior to distillation. Additionally, an internal standard $\left(\mathrm{Me}^{201} \mathrm{Hg}\right)$ was added to correct for procedural recoveries. Samples were distilled on a hot plate at $500{ }^{\circ} \mathrm{C}$ for approximately four hours until $80 \%$ of the sample volume was in the receiving vial. The distillate was then ethylated with sodium tetraethyl borate (NaTEB), followed by purge and trap of volatile Hg species on Tenax trap. Tenax traps were thermally desorbed into a GC glass column (packed with 15\% OV-3 Chromosorb; 60/80 mesh) to achieve separation of Hg species, which were detected using an ICP-MS (Agilent Technologies 7700 series). Samples were run with method blanks, duplicates $(\mathrm{RSD}<10 \%)$, and matrix spikes (100$111 \%$ recovery) every 10 samples for quality assurance, and the method detection limit (MDL) was $0.007 \mathrm{ng} \mathrm{L}^{-1}$. MeHg analysis of samples at CCIW was carried out as described above (distillation, ethylation with NaBEt4, GC separation), but with cold vapor atomic fluorescence spectrophotometry (CVAFS) detection ${ }^{7,8}$ using a Brooks Rand MERX MeHg analyzer. For the CVAFS method, mean sample spike recovery was $97 \%$, duplicates were typically within $10 \%$ of each other, and the MDL, calculated as $3 x$ the standard deviation of the blank, was $0.014 \mathrm{ng} \mathrm{L}^{-1}$.

THg in water and snow samples were analyzed following US EPA method $1631{ }^{8}$ through $\mathrm{BrCl}$ oxidation, $\mathrm{SnCl}_{2}$ reduction, gold trap amalgamation and Cold Vapour Atomic Fluorescence Spectroscopy (CVAFS) detection using either a Tekran 2600 (BASL) or Tekran 2500 (CCIW). The MDL was $0.06 \mathrm{ng} \mathrm{L}^{-1}$ (BASL) and $0.03 \mathrm{ng} \mathrm{L}^{-1}$ (CCIW). Duplicates $(\mathrm{RSD}<3 \%)$, and matrix spikes (98\% recovery) were used for quality assurance.

THg concentrations of isotope tracers in soils and sediments were measured by digesting $0.3 \mathrm{~g}$ of homogenized, freeze-dried sub-samples with $10 \mathrm{~mL}$ of concentrated nitric acid and heated on a hot plate. $\mathrm{BrCl}$ oxidized digest solution was analyzed using an automated Tekran 2600-ICP-MS system where $\mathrm{Hg}(\mathrm{II})$ is reduced, using $\mathrm{SnCl}_{2}$, to elemental $\mathrm{Hg}\left(\mathrm{Hg}^{0}\right)$, which is then undergoes dual pre-concentration on gold traps, thermal 
desorption into the ICP-MS (Agilent Technologies, 7700 series), using a stream of Ar carrier gas, for quantification of the signal response of individual isotopes. ${ }^{6}$ Method blanks, duplicates ( $\mathrm{RSD}<4 \%$ ), and a certified reference material (MESS-4) were used for quality assurance. All MESS-4 measurements were within the certified concentration range (certified concentration: $90 \pm 40 \mathrm{ng} \mathrm{g}^{-1}$; measured concentration: $89 \pm 7 \mathrm{ng} \mathrm{g}^{-1}$ ), and within $5 \%$ of each other.

Total Hg in soil samples were analyzed using a tri-cell Direct Mercury Analyzer 80 (DMA-80), based on U.S. EPA method $7473 .{ }^{10}$ Subsamples $(50 \mathrm{mg}$ ) were placed in a precombusted nickel boat, thermal decomposed, amalgamation of the released $\operatorname{Hg}(0)$, and detection by atomic absorption spectrometry. The DMA- 80 program was set to dry samples at $200{ }^{\circ} \mathrm{C}$ for one minute and decompose samples at $650^{\circ} \mathrm{C}$ for two minutes. The method detection limit, calculated as three times the standard deviation of the blank (boat blanks), was $0.03 \mathrm{ng} \mathrm{g}^{-1}$. Samples were run in duplicates $(\% \mathrm{RSD}<10 \%)$, with blanks $(<0.0002 \mathrm{ng} \mathrm{g}$ ${ }^{1}$ ), and MESS-3 standard reference material (certified concentration: $91 \pm 9 \mathrm{ng} \mathrm{g}^{-1}$; measured concentration: $92 \pm 9 \mathrm{ng} \mathrm{g}^{-1}$ ) run every 12 samples for QA/QC purposes.

Water chemistry analyses were performed at the ISO/IEC 17025-certified Biogeochemical Analytical Service Laboratory (BASL, University of Alberta), using standard certified protocols. BASL is accredited by the Canadian Association of Laboratory Accreditation (CALA) for these analyses.

Data Analysis: Potential methylation rate constants $\left(k_{m}, \mathrm{~d}^{-1}\right)$ in soil and sediment samples were calculated as the proportion of added ${ }^{198} \mathrm{Hg}$ that was converted into $\mathrm{Me}^{198} \mathrm{Hg}$, divided by the incubation time. ${ }^{2}$ Potential demethylation rate constants $\left(k_{d}, \mathrm{~d}^{-1}\right)$ were calculated based on pseudo-first order kinetics following equation 1, where $\mathrm{MeHg}_{0}$ and $\mathrm{MeHg}_{\mathrm{t}}$ refer to the concentrations at the start and end, respectively, of the incubation with a duration of time $=\mathrm{t}$ and $\mathrm{MeHg}_{0}$ is estimated from the theoretical amount of $\mathrm{Me}^{199} \mathrm{Hg}$ injected into the sediment: ${ }^{2}$

$k_{d}=-\frac{1}{t} \ln \left(\frac{M e H g_{t}}{M e H g_{0}}\right)$ 
Potential methylation and demethylation rates in lake water samples were below detection limit (MDL= 0.022-0.046 d-1 and 0.064-0.132 $\mathrm{d}^{-1}$ for $k_{m}$ and $k_{d}$, respectively), calculated according to Hintelmann and Evans. ${ }^{6} k_{m}$ and $k_{d}$ in solid snow and snowmelt were calculated according to Willis et al. ${ }^{5}$ The decreasing bioavailability and reactivity of the $\mathrm{Hg}(\mathrm{II})$ spike over time during snow incubations was estimated by adapting experimentally determined rates from pristine snow reported by Willis et al. ${ }^{5}$ Detection limits for rates of methylation and demethylation were calculated according to Hintelmann and Evans ${ }^{6}$ (Equation 2):

cnew $\geq b g \times A \times 3 R S D$

In the equation above, cnew is the concentration of minimum concentration of newly generated species from the tracer isotope that can be measured, $b g$ is the background concentration of species of interest (e.g., MeHg), $A$ represents the natural abundance of tracer isotope used, and RSD is the relative standard deviation (RSD) of isotope ratio measurements (tracer isotope/reference isotope).

Standard statistical analyses were performed to determine if sets of samples were significantly different from one another. Each dataset was assessed using two-tailed, nonpaired t-tests (ttest2) or ANOVA test (anova) $(p=0.05)$ using MATLAB® R2016a. Each dataset was assessed to ensure that it met the assumptions of each test (normality, normal distribution of residuals, and independence of residuals where applicable).

\section{RESULTS AND DISCUSSION}

\section{Within season variation in Skeleton Continuum surface waters (July-August}

2015/2016): In 2015, hydrological connectivity between the ponds and wetland (and Skeleton Creek) was not established until between July 13-18. There were small amounts of variation in surface water THg concentrations within the season at each site. Most of the variation that was observed was accounted for by changes in the particulate bound $\mathrm{Hg}$, which can be seen when comparing panels (a) and (b) in Figure S1. MeHg concentrations were more variable, with notably higher concentrations on certain dates, for example at the wetland outflow on July $18\left(0.17 \mathrm{ng} \mathrm{L}^{-1}\right)$ and after the ponds at the wetland inflow on August 1 (0.49 $\left.\mathrm{ng} \mathrm{L}^{-1}\right)$ (Figure S1 c-d). The increase at the wetland outflow on July 18 is 
caused by an increase in particulate bound $\mathrm{MeHg}$, but concentrations returned to much lower levels (0.03 ng L ${ }^{-1}$ ) by July 23 (Figure S1 d). The very large increase in MeHg concentrations at the wetland inflow on August 1 was due to an increase in both dissolved and particulate bound MeHg (Figure S1 c-d).

In 2016, Skeleton Lake was free of ice by July 2 and hydrologic connectivity between the ponds and wetland outflow (and Skeleton Creek) was established by July 17. Surface water THg concentrations showed minimal variation and were primarily driven by changes in particulate bound THg, similar to 2015 (Figure S2 a-b). MeHg concentrations showed little variability throughout 2016 (Figure S2 c-d).

In 2015 and 2016, \%MeHg was always greatest at the wetland inflow with a range of 17-51\%. In both years the high seasonal average \% MeHg is largely driven by an increase in \% MeHg that occurred later in summer, on August 1 and July 31 for 2015 and 2016, respectively (Figure S3 a-b). In 2015, the high \%MeHg value coincides with an increase in both THg and MeHg concentrations, whereas in 2016, the high \%MeHg value coincides with relatively low THg concentrations.

Photodemethylation Estimates during Ice Melt: In the spring when there is no hydrological connectivity, the Skeleton Lake water column stores 4-times more $\mathrm{MeHg}_{\mathrm{T}}$ than in the summer, and there is therefore a large reduction in water column $\mathrm{MeHg}$ concentrations during the transistion from the ice-covered to the the ice-free period. Assuming water MeHg concentrations are relatively similar between years, which our data support, we see a reduction in $\mathrm{MeHg}_{\mathrm{T}}$ of $0.47 \mathrm{ng} \mathrm{L}^{-1}$ over a period of 27 days (June 6 to July 3). MeHg photodemethylation was estimated in the Skeleton Lake water column for the 11 days between ice-off (June 22) and the first summer sample date (July 3) based on spring time $\mathrm{MeHg}_{\mathrm{T}}$ concentrations (0.282 $\mathrm{ng} \mathrm{L}^{-1}$, taking into account dilution from ice-melt), DOC concentrations (6 mg L), light attenuation $\left(k=0.51 \mathrm{~m}^{-1}\right)$, and cumulative daily PAR (57.3 mol m $\mathrm{m}^{-2} \mathrm{~d}^{-1}$ ), following the method of Lehnherr and St. Louis. ${ }^{11}$ Dilution of MeHg by ice-melt and photodemethylation in the water column over this time frame can explain a reduction in $\mathrm{MeHg}_{\mathrm{T}}$ concentrations from $0.55 \mathrm{ng} \mathrm{L}^{-1}$ to $0.12 \mathrm{ng} \mathrm{L}^{-1}$. This suggests that while MeHg can 
accumulate during the ice-covered period to reach elevated concentrations, a portion of MeHg produced in the ice-covered period may undergo photodemethylation before it can be transported downstream. However, these calculations also suggest that a significant portion of the Skeleton Lake $\mathrm{MeHg}_{\mathrm{T}}$ pool is not lost via photodemethylation (summer concentrations are $0.06 \mathrm{ng} \mathrm{L}^{-1}$ compared to $0.12 \mathrm{ng} \mathrm{L}^{-1}$ estimated to remain after photodemethylation), implying that sufficient MeHg remains for uptake by zooplankton and/or downstream export. These calculations also assume that there is little downstream transport during the snowmelt period, which may not be true because partial ice cover allows for snowmelt waters to enter the lake and flush lake waters downstream, thus potentially facilitating downstream MeHg export before it can be photodemethylated. 


\section{SUPPLEMENTARY FIGURES}

$\rightarrow$ 09-Jul $\rightarrow$-13-Jul $\rightarrow-18-J u l \rightarrow 23-J u l \rightarrow 01-A u g$
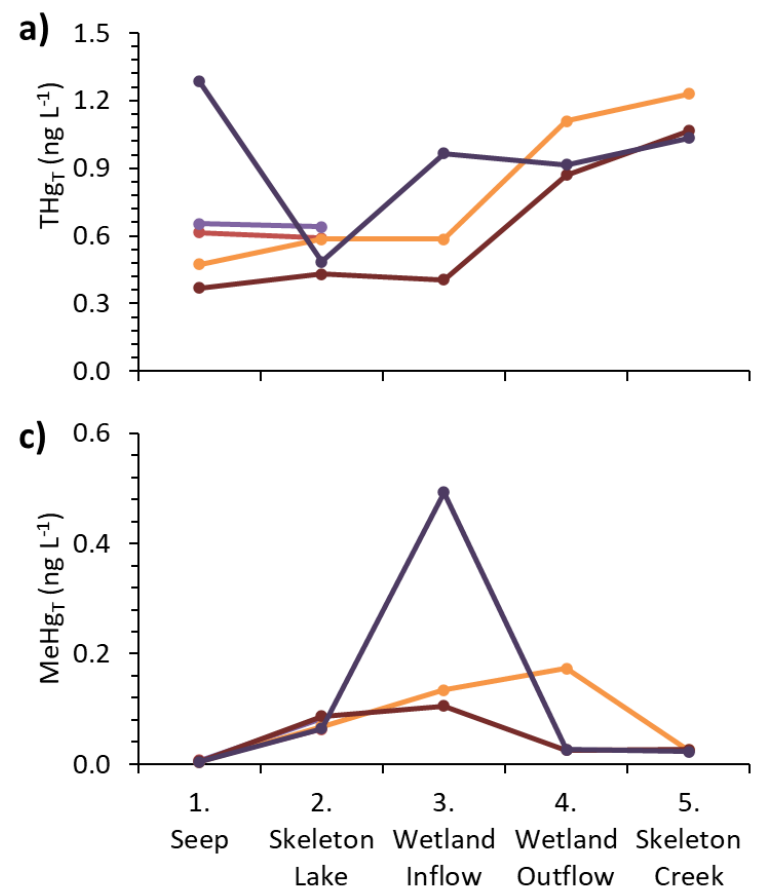
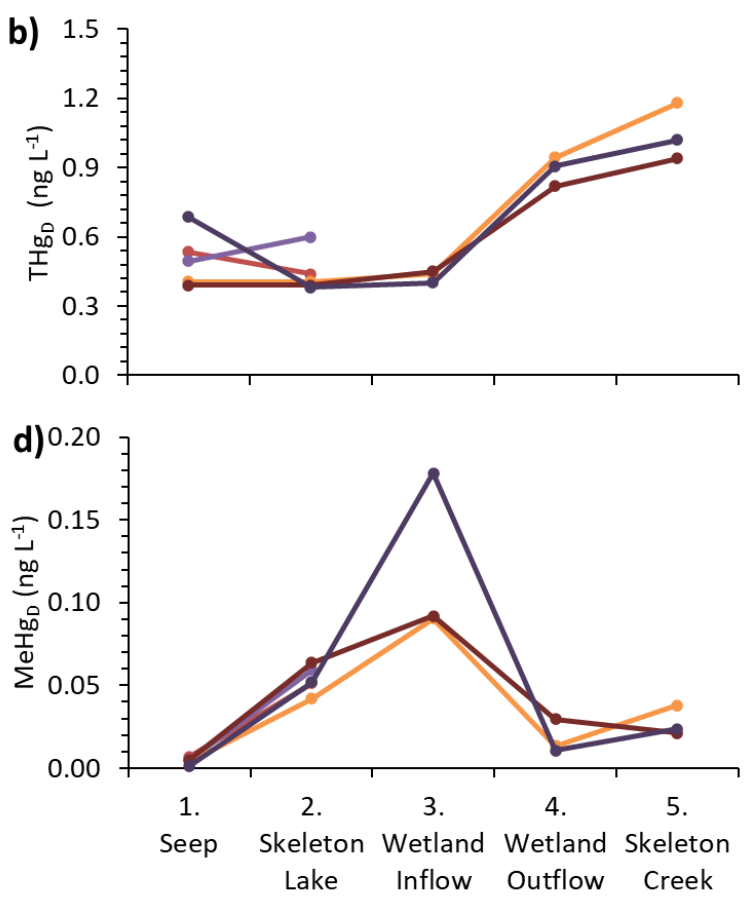

Figure S1. Surface water concentrations of Hg species in the Skeleton Continuum throughout the 2015 open water summer season. (a) total (dissolved + particulate bound) THg ( $\mathrm{THg}_{\mathrm{T}}$ ); (b) dissolved THg ( $\left.\mathrm{THg}_{\mathrm{D}}\right)$; (c) total MeHg ( $\left.\mathrm{MeHg}_{\mathrm{T}}\right)$; and (d) dissolved $\mathrm{MeHg}$ $\left(\mathrm{MeHg}_{\mathrm{D}}\right)$. 
$\rightarrow$ 03-Jul $\rightarrow$ 09-Jul $\rightarrow$ 17-Jul $\rightarrow$ 25-Jul $\rightarrow$ 31-Jul $\rightarrow \bullet 06-$ Aug
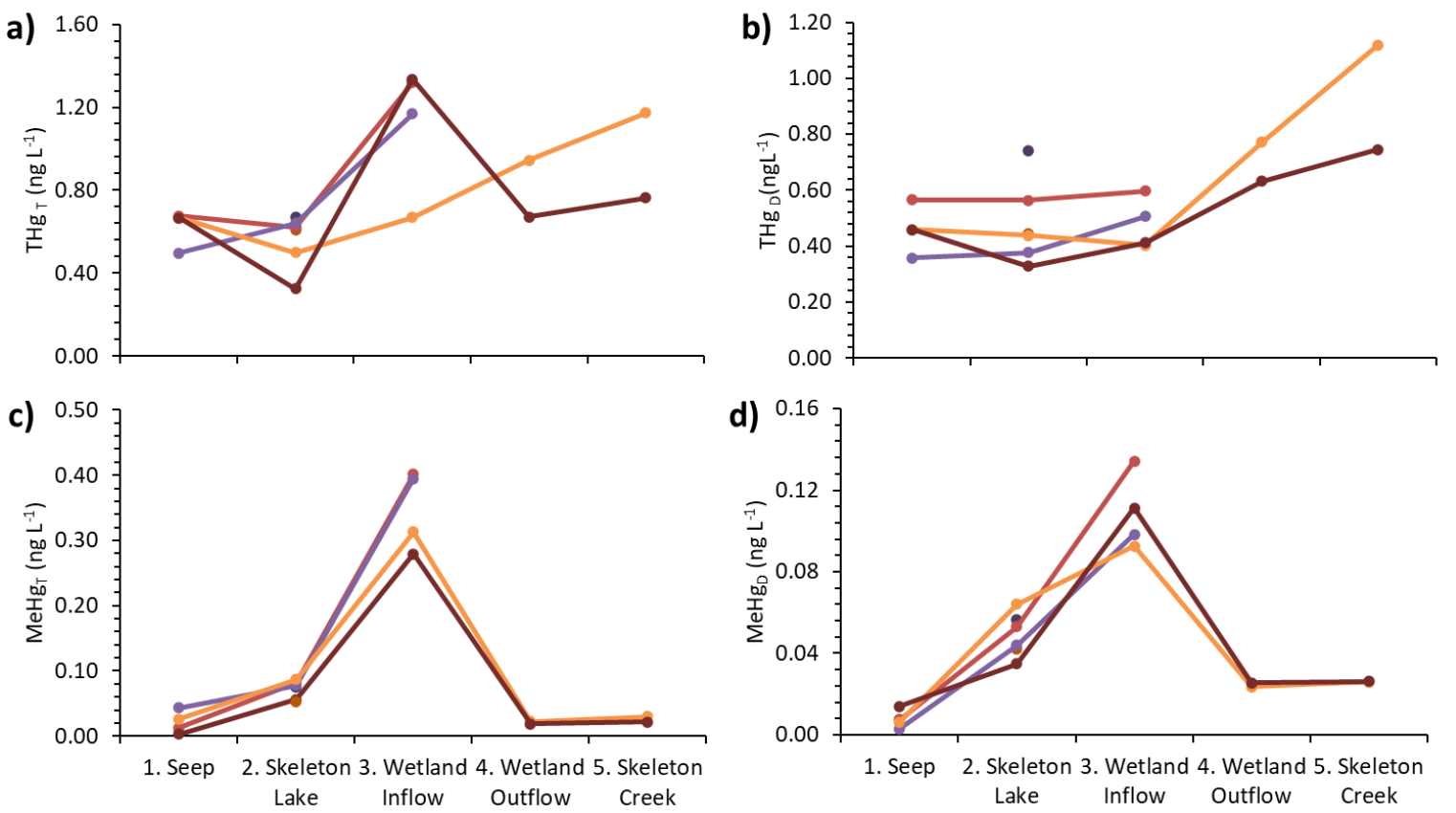

Figure S2. Surface water concentrations of Hg species in the Skeleton Continuum throughout the 2016 open water summer season. (a) total (dissolved + particulate bound) THg ( $\mathrm{THg}_{\mathrm{T}}$ ); (b) dissolved THg ( $\left.\mathrm{THg}_{\mathrm{D}}\right)$; (c) total $\mathrm{MeHg}\left(\mathrm{MeHg}_{\mathrm{T}}\right)$; and (d) dissolved $\mathrm{MeHg}$ $(\mathrm{MeHg})$. 


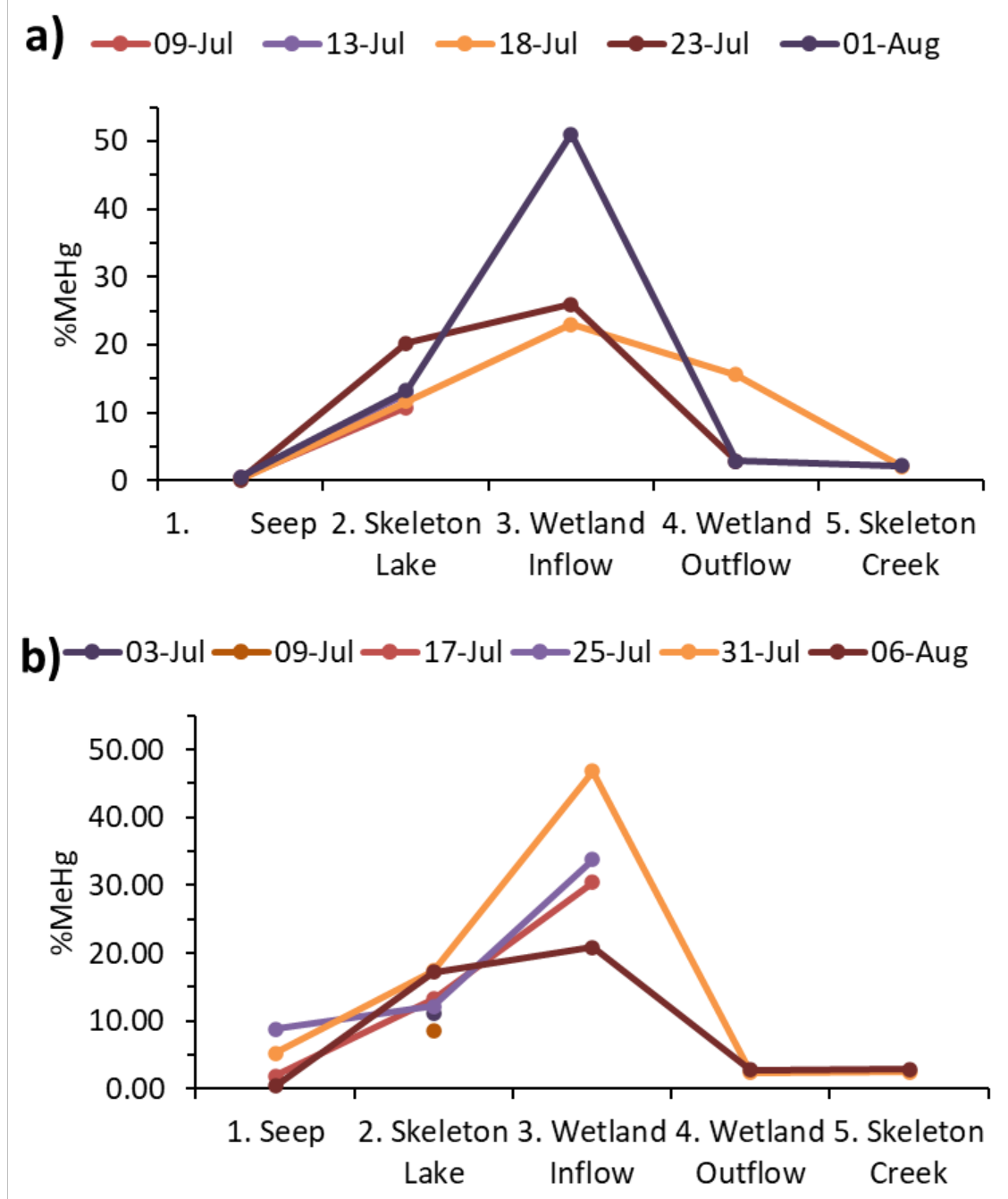

Figure S3. Proportion of $\mathrm{THg}_{\mathrm{T}}$ as $\mathrm{MeHg}_{\mathrm{T}}\left(\% \mathrm{MeHg}_{\mathrm{T}}\right)$ in Skeleton Continuum surface water throughout the summer open water season in (a) 2015, and (b) 2016. 

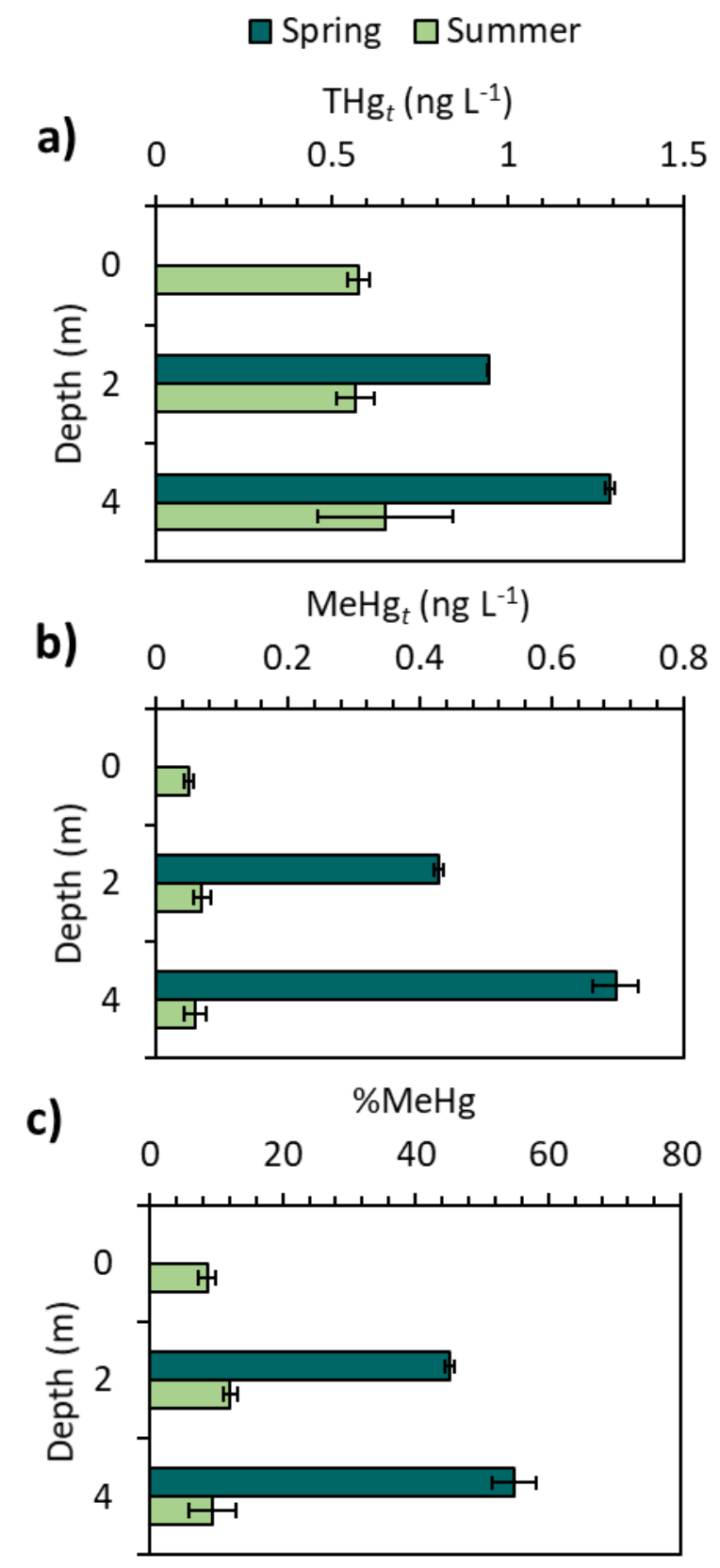

Figure S4. Concentrations of (a) $\mathrm{THg}_{\mathrm{T}}$ and (b) $\mathrm{MeHg}_{\mathrm{T}}$, and c) $\% \mathrm{MeHg}_{\mathrm{T}}$ at different depths in the Skeleton Lake water column during spring and summer. 


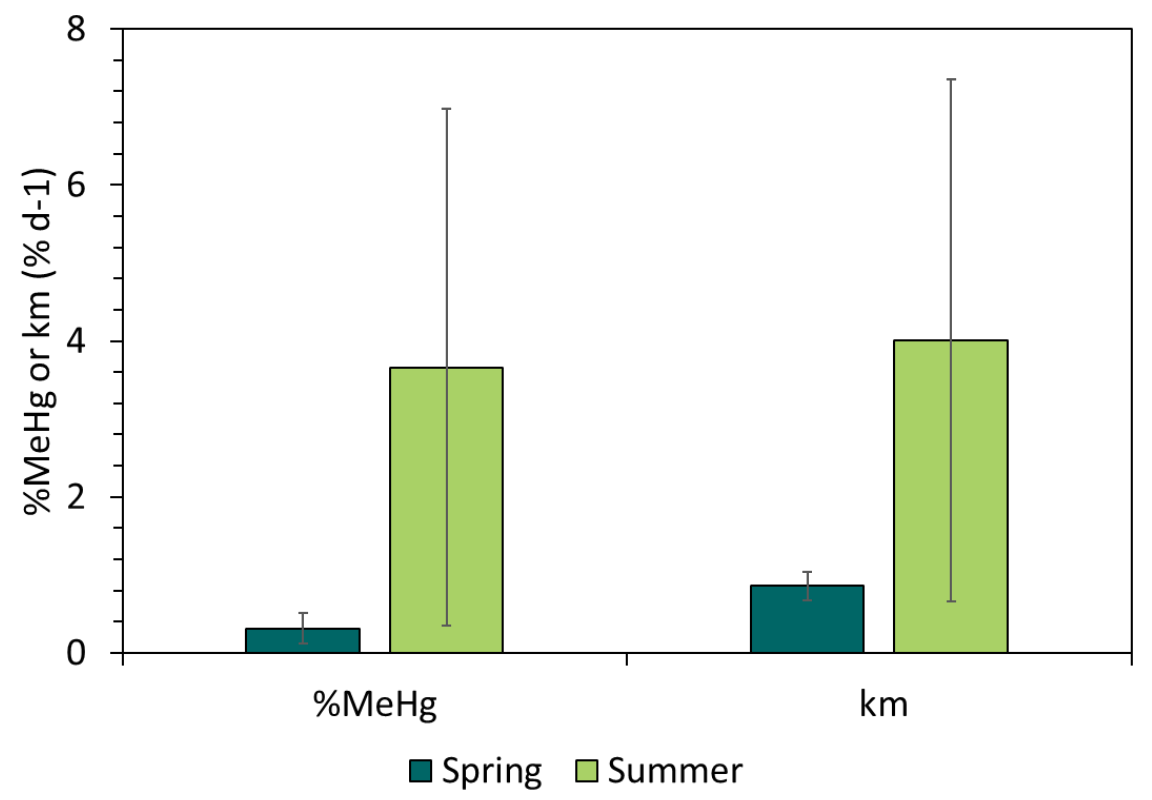

Figure S5. \%MeHg and $\mathrm{Hg}$ methylation potential $\left(k_{m}, \% \mathrm{~d}^{-1}\right)$ in Skeleton Lake sediment during the summer (open water) and spring (ice-covered) seasons.
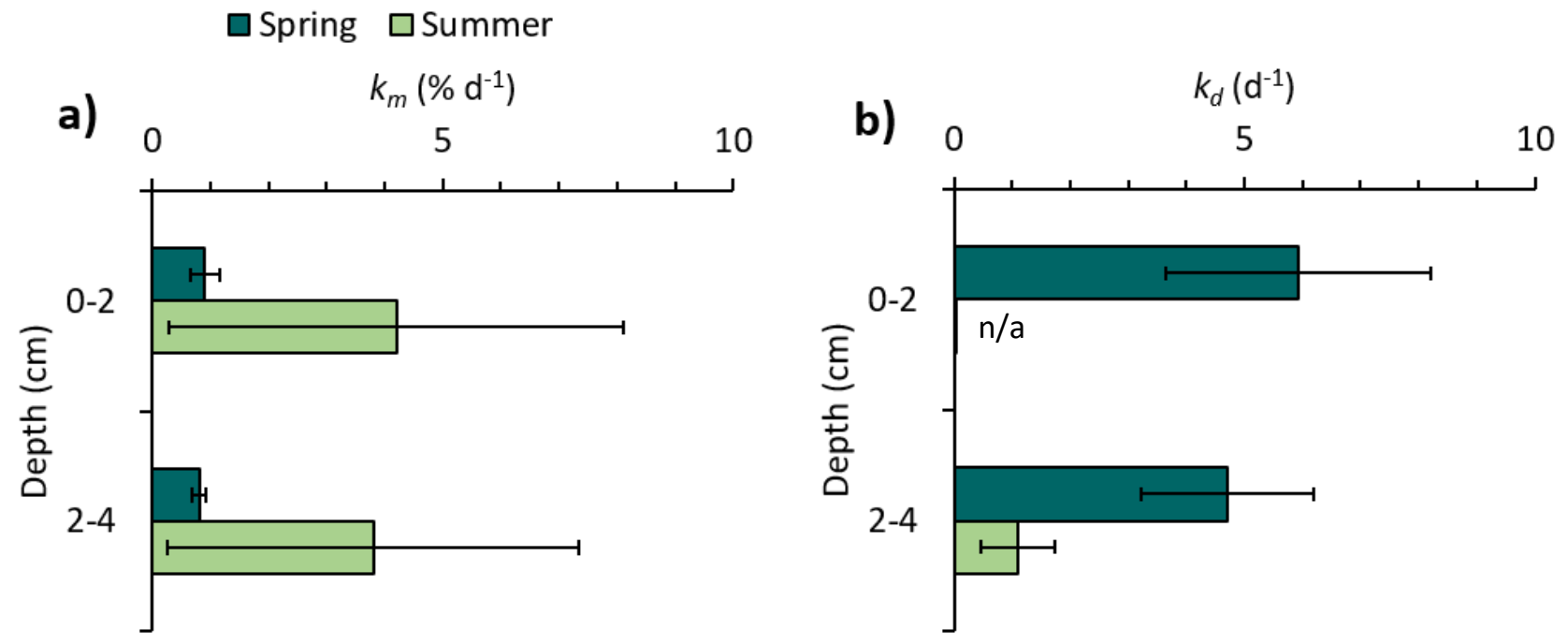

Figure S6. Potential rate constants of a) $\mathrm{Hg}$ methylation $\left(k_{m}, \% \mathrm{~d}^{-1}\right)$ and b) demethylation $\left(k_{d}, \mathrm{~d}^{-1}\right)$ at various depths below the sediment-water interface in Skeleton Lake Sediments ( $n=2-3$ per interval) during the summer (open water) and spring (ice-covered) seasons. 
$\square$ Skeleton Lake $\square$ Pond 11

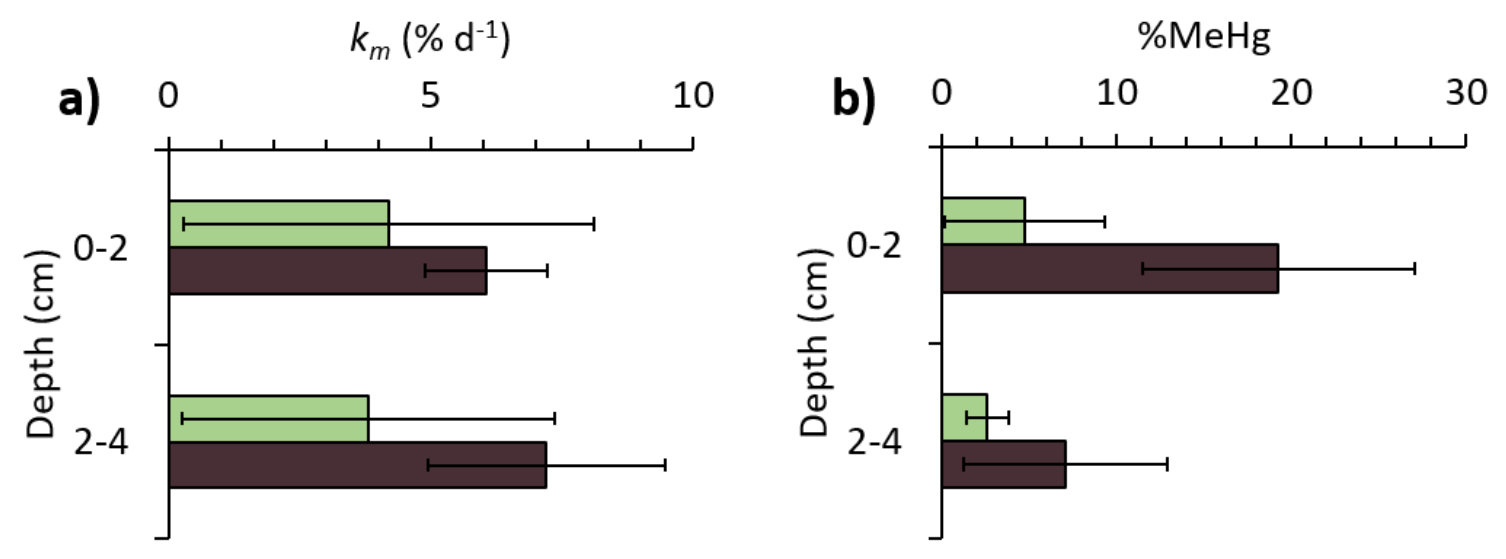

Figure S7. a) Methylation potential $\left(k_{m}, \% \mathrm{~d}^{-1}\right)$ and b) $\% \mathrm{MeHg}$ at various depths below the sediment-water interface in Skeleton Lake and Pond 11 sediments ( $n=2-3$ per interval). 


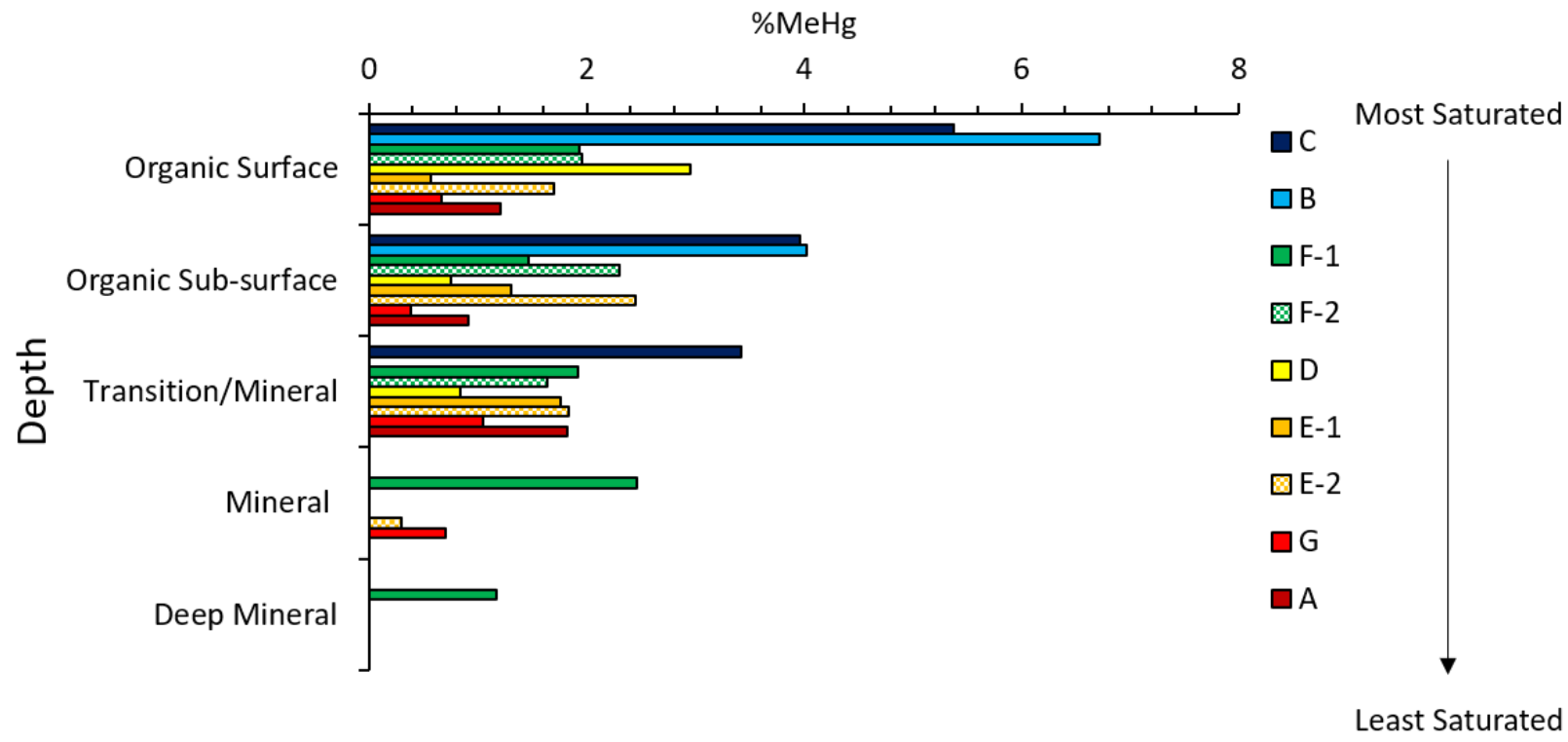

Figure S8. \%MeHg in wetland soil (wetland mid-point) arranged by soil horizon and saturation. Each colour represents a single coring site along the transect (A-G, see Figure 1 for transect location); duplicate cores (hatched) were taken within $30 \mathrm{~cm}$ of each other. For each soil horizon, the bars are organized top to bottom by soil moisture content, from the most to the least saturated site, similar to the figure legend.

$\square$ Wetland Inflow $\quad \square$ Wetland Mid-point
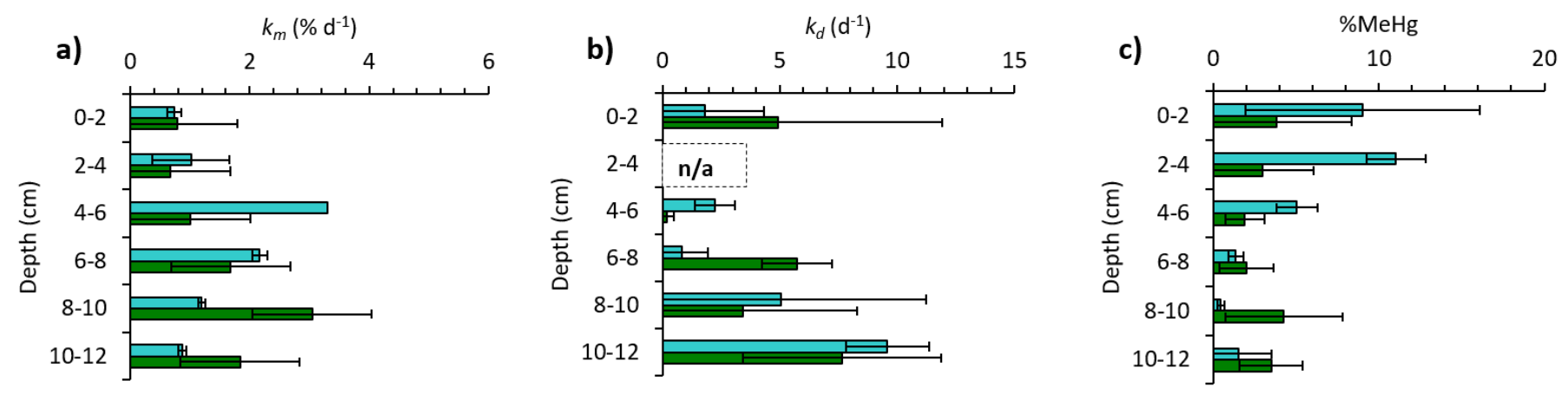

Figure S9. Potential rates of (a) methylation $\left(k_{m}, \% \mathrm{~d}^{-1}\right)$ and (b) demethylation $\left(k_{d}, \mathrm{~d}^{-1}\right)$, and (c) $\% \mathrm{MeHg}$ in wetland soils ( $n=1-3$ per depth interval) at the Skeleton Continuum wetland inflow and midpoint sites. 


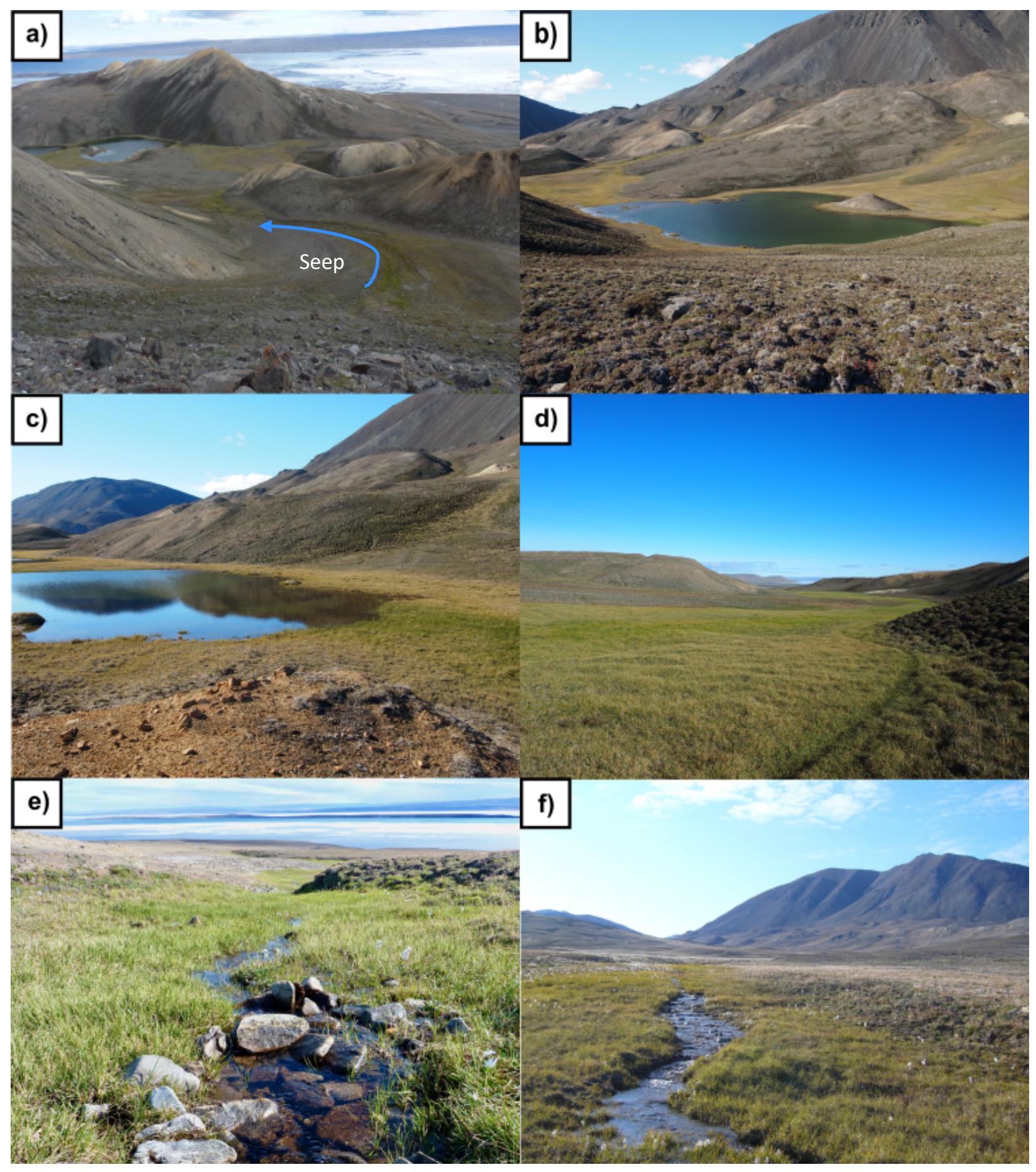

Figure S10. Skeleton Continuum sampling sites. a) Active layer seep, b) Skeleton Lake, c) Wetland inflow immediately downstream of Pond 11, d) Wetland sedge meadow, e) Wetland outflow, and (f) Skeleton Creek. 
a)
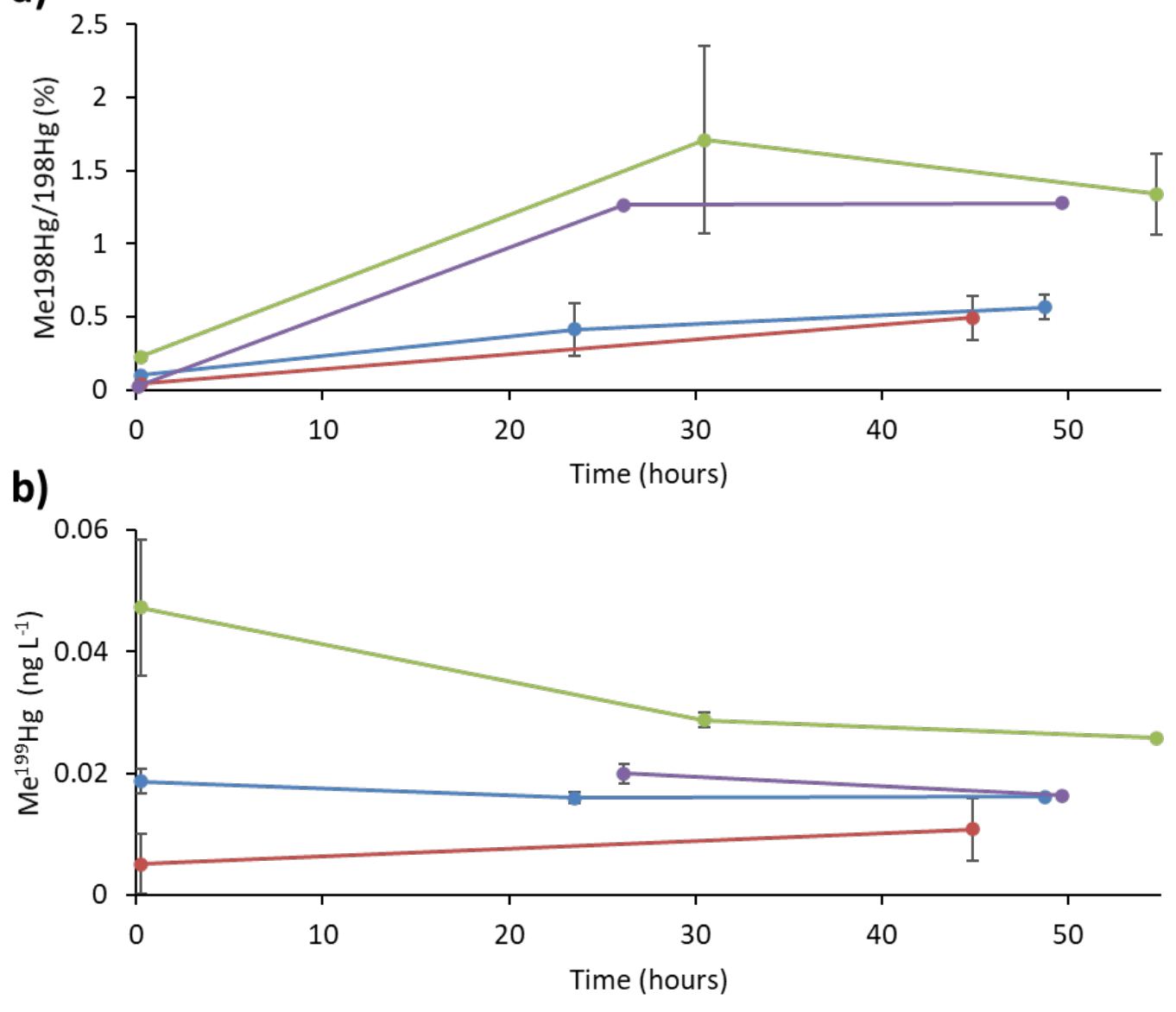

$\rightarrow-$ Skeleton Lake Snowmelt $\rightarrow-$ Skeleton Creek Snowmelt

$\rightarrow$ Skeleton Lake Snowpack $\rightarrow-$ Skeleton Creek Snowpack

Figure S11. a) $\mathrm{Hg}(\mathrm{II})$ methylation in solid snow and snowmelt shown as the percentage of added reactive ${ }^{198} \mathrm{Hg}$ (II) converted to $\mathrm{Me}^{198} \mathrm{Hg}$ over time. b) MeHg demethylation in solid snow and snowmelt shown as the decrease in added $\mathrm{Me}^{199} \mathrm{Hg}$ over time. 


\section{SUPPLEMENTARY TABLES}

Table S1. Incubation times (h) and final stable isotope spike concentrations ( $\mathrm{ng} \mathrm{L}^{-1} \mathrm{or} \mathrm{ng} \mathrm{cm}^{-3}$ ) in incubated samples for methylation $\left({ }^{198} \mathrm{Hg}\right)$ and demethylation $\left(\mathrm{Me}^{199} \mathrm{Hg}\right)$ assay experiments in water, sediment/soil, snowpack, and snowmelt

\begin{tabular}{cccc}
\hline Media & $\begin{array}{c}\text { Incubation } \\
\text { Times (h) }\end{array}$ & $\begin{array}{c}{ }^{198} \mathrm{Hg} \\
\text { (purity 90.5 \%) }\end{array}$ & $\begin{array}{c}\mathrm{Me}^{199} \mathrm{Hg} \\
\text { (purity 91.5 \%) }\end{array}$ \\
\hline Water & $0,6,16$ and 28 & $2.160 \mathrm{ng} \mathrm{L}^{-1}$ & $0.109 \mathrm{ng} \mathrm{L}^{-1}$ \\
Sediment/Soil & 0,5 & $3.96 \mathrm{ng} \mathrm{cm}^{-3}$ & $0.013 \mathrm{ng} \mathrm{cm}^{-3}$ \\
Snowpack & 0,24 and 48 & $0.003 \mathrm{ng} \mathrm{cm}^{-3}$ & $0.00001 \mathrm{ng} \mathrm{cm}^{-3}$ \\
Snowmelt & 0,24 and 48 & $4.1035 \mathrm{ng} \mathrm{L}^{-1}$ & $0.0229 \mathrm{ng} \mathrm{L}^{-1}$ \\
\hline
\end{tabular}

Table S2. Mean ( \pm standard deviation) concentrations for various water chemistry parameters in Skeleton Lake, spring 2017 and summer 2016. (n/a= data not available). (DO - dissolved oxygen; TP - total phosphorous; DOC - dissolved organic carbon; PC - particulate carbon; $\mathrm{Cl}^{-}$- chloride; $\mathrm{SO}_{4}{ }^{2-}$ - sulfate; TDS - total dissolved solids; Chl-a - chlorophyll a; TSS - total suspended solids; $\mathrm{CH}_{4}$ - methane; $\mathrm{NH}_{4}{ }^{+}: \mathrm{NO}_{3}{ }^{-}$- ammonium to nitrate ratio)

\begin{tabular}{|c|c|c|c|c|c|c|c|c|c|c|c|}
\hline & $\begin{array}{c}\text { DO } \\
\left(\mathrm{mg} \mathrm{L}^{-1}\right)\end{array}$ & $\begin{array}{c}\mathrm{TP} \\
\left(\mu \mathrm{g} \mathrm{L}^{-1}\right)\end{array}$ & $\begin{array}{c}\text { DOC } \\
\left(\mathrm{mg} \mathrm{L}^{-1}\right)\end{array}$ & $\begin{array}{c}P C \\
\left(\mu g ~^{-1}\right)\end{array}$ & $\begin{array}{c}\mathrm{Cl}^{-} \\
\left(\mathrm{mg} \mathrm{L}^{-1}\right)\end{array}$ & $\begin{array}{c}\mathrm{SO}_{4}{ }^{2-} \\
\left(\mathrm{mg} \mathrm{L}^{-1}\right)\end{array}$ & $\begin{array}{c}\text { TDS } \\
\left(\mathrm{mg} \mathrm{L}^{-1}\right)\end{array}$ & $\begin{array}{c}\text { Chl-a } \\
\left(\mu \mathrm{L} \mathrm{L}^{-1}\right)\end{array}$ & $\begin{array}{c}\text { TSS } \\
\left(\mathrm{mg} \mathrm{L}^{-1}\right)\end{array}$ & $\begin{array}{c}\mathrm{CH}_{4} \\
\left.(\mu \mathrm{mol} \mathrm{L})^{-1}\right)\end{array}$ & $\mathrm{NH}_{4}{ }^{+}: \mathrm{NO}_{3}$ \\
\hline Spring & $\begin{array}{c}3.43 \\
( \pm 0.22)\end{array}$ & $\begin{array}{c}6.50( \pm \\
0.58)\end{array}$ & $\begin{array}{c}8.18 \\
( \pm 0.17)\end{array}$ & $\begin{array}{c}22.1 \\
( \pm 0.7)\end{array}$ & $\begin{array}{c}3.46 \\
( \pm 0.01)\end{array}$ & $\begin{array}{c}421.7 \\
( \pm 3.78)\end{array}$ & $\begin{array}{c}822.3 \\
( \pm 24.1)\end{array}$ & $\begin{array}{c}0.98 \\
( \pm 0.31)\end{array}$ & $\begin{array}{c}1.75 \\
( \pm 0.65)\end{array}$ & $\begin{array}{c}2.90 \\
( \pm 5.9)\end{array}$ & 1.02 \\
\hline Summer & $\begin{array}{c}11.7 \\
( \pm 1.25)\end{array}$ & $\begin{array}{c}2.75 \\
( \pm 0.46)\end{array}$ & $\begin{array}{c}5.98 \\
( \pm 0.18) \\
\end{array}$ & $\begin{array}{c}207.2 \\
( \pm 69.0)\end{array}$ & $\begin{array}{c}2.22 \\
( \pm 0.01)\end{array}$ & $\begin{array}{c}262.8 \\
( \pm 2.50)\end{array}$ & $\begin{array}{r}510.1 \\
( \pm 29.0) \\
\end{array}$ & $\begin{array}{c}0.78 \\
( \pm 0.22) \\
\end{array}$ & $\mathrm{n} / \mathrm{a}$ & $\begin{array}{c}0.02 \\
( \pm 0.02)\end{array}$ & 18.1 \\
\hline
\end{tabular}


Table S3. Cryoconcentration of solutes in Skeleton Lake as a result of lake ice formation.

\begin{tabular}{lcc}
\hline Conservative Tracers & $\mathrm{Cl}\left(\mathrm{mg} \mathrm{L}^{-1}\right)$ & TDS $\left(\mathrm{mg} \mathrm{L}^{-1}\right)$ \\
\hline Summer & 2.22 & 510.13 \\
Spring & 3.46 & 822.25 \\
\hline $\begin{array}{l}\text { Cryoconcentration Estimate } \\
\text { (fractional increase) }\end{array}$ & 1.56 & 1.61 \\
\hline
\end{tabular}

Table S4. Skeleton Lake water column THg and MeHg pools in spring (under ice) and summer (open water).

\begin{tabular}{lccccc}
\hline Season & $\begin{array}{c}\text { Skeleton Lake } \\
\text { Volume (L) }\end{array}$ & $\begin{array}{c}\mathrm{THg}_{\mathbf{T}} \\
\left(\mathbf{n g ~ L}^{-1}\right)\end{array}$ & $\begin{array}{c}\mathbf{M e H g}_{\mathbf{T}} \\
\left(\mathbf{n g ~ L}^{-1}\right)\end{array}$ & $\begin{array}{c}\mathbf{T H g}_{\boldsymbol{T}} \text { pool } \\
(\mathbf{m g})\end{array}$ & $\begin{array}{c}\mathbf{M e H g}_{\mathbf{T}} \text { pool } \\
(\mathbf{m g})\end{array}$ \\
\hline Spring & 15644590 & 1.12 & 0.56 & 17.51 & 8.80 \\
Summer & 36382010 & 0.62 & 0.077 & 22.64 & 2.78 \\
\hline
\end{tabular}

Table S5. Skeleton Lake zooplankton THg and MeHg pools in spring (under ice) and summer (open water).

\begin{tabular}{lllllllll}
\hline Season & $\begin{array}{l}\text { Skeleton } \\
\text { Lake } \\
\text { Volume (L) }\end{array}$ & $\begin{array}{l}\text { Biomass } \\
\left(\mathbf{m g ~ m}^{-3}\right)\end{array}$ & $\begin{array}{l}\text { THg } \\
\left.\mathbf{( n g ~ g}^{-1}\right)\end{array}$ & $\begin{array}{l}\text { MeHg } \\
\left.\mathbf{( n g ~ g}^{-1}\right)\end{array}$ & $\begin{array}{l}\text { THg } \\
\left(\mathbf{n g ~ L}^{-1}\right)\end{array}$ & $\begin{array}{l}\text { MeHg } \\
\left(\mathbf{n g ~ L}^{-1}\right)\end{array}$ & $\begin{array}{l}\text { THg } \\
\text { Pool } \\
(\mathbf{m g})\end{array}$ & $\begin{array}{l}\text { MeHg } \\
\text { Pool } \\
(\mathbf{m g})\end{array}$ \\
\hline Spring & 15644590 & 92.89 & 52.50 & 14.50 & 0.0049 & 0.0013 & 0.08 & 0.021 \\
Summer & 36382010 & 141.31 & 116.22 & 73.72 & 0.02 & 0.01 & 0.61 & 0.42 \\
\hline
\end{tabular}


Table S6. Potential methylation $\left(k_{m}\right)$ and demethylation $\left(k_{d}\right)$ rate constants, and \% $\mathrm{MeHg}$ in wetland soils by $2 \mathrm{~cm}$ depth intervals ( $n=1-3$ per interval) at the Skeleton Continuum wetland inflow (transect 1 ) and midpoint (transect ??). Table shows means ( \pm standard deviations). $\mathrm{n} / \mathrm{a}=$ data not available.

\begin{tabular}{lcccc}
\hline Site & Depth $(\mathbf{c m})$ & $\boldsymbol{k}_{m}\left(\% \mathbf{d}^{-1}\right)$ & $\boldsymbol{k}_{d}\left(\mathbf{d}^{-1}\right)$ & $\% \mathrm{MeHg}$ \\
\hline Wetland Inflow & $0-2$ & $0.73( \pm 0.17)$ & 3.58 & $9.02( \pm 7.06)$ \\
& $2-4$ & $1.02( \pm 0.91)$ & $\mathrm{n} / \mathrm{a}$ & $11.05( \pm 1.76)$ \\
& $4-6$ & 3.31 & $2.23( \pm 0.85)$ & $5.06( \pm 1.23)$ \\
& $6-8$ & $2.17( \pm 0.18)$ & $0.85( \pm 1.09)$ & $1.36( \pm 0.46)$ \\
& $8-10$ & $1.20( \pm 0.08)$ & $5.04( \pm 6.19)$ & $0.47( \pm 0.23)$ \\
Wetland & $10-12$ & $0.87( \pm 0.09)$ & $9.59( \pm 1.77)$ & $1.54( \pm 2.00)$ \\
Midpoint & $0-2$ & $0.79( \pm 0.11)$ & 9.89 & $3.83( \pm 4.54)$ \\
& $2-4$ & $0.67( \pm 0.20)$ & $\mathrm{n} / \mathrm{a}$ & $3.00( \pm 3.08)$ \\
& $4-6$ & $1.00( \pm 0.43)$ & 0.41 & $1.90( \pm 1.18)$ \\
& $6-8$ & $1.68( \pm 2.16)$ & $5.72( \pm 1.49)$ & $2.01( \pm 1.62)$ \\
& $8-10$ & $3.04( \pm 2.74)$ & 6.88 & $4.28( \pm 3.54)$ \\
& $10-12$ & $1.84( \pm 1.42)$ & $7.64( \pm 4.22)$ & $3.51( \pm 1.90)$ \\
\hline
\end{tabular}


Table S7. Snow water equivalence (SWE, $\mathrm{km} \mathrm{m}^{-2}$ ), total and dissolved THg and MeHg concentrations (ng L-1), loadings (mg ha${ }^{1}$ ), and \%MeHg in snowpacks sampled over land and over lake ice in the Skeleton Continuum.*

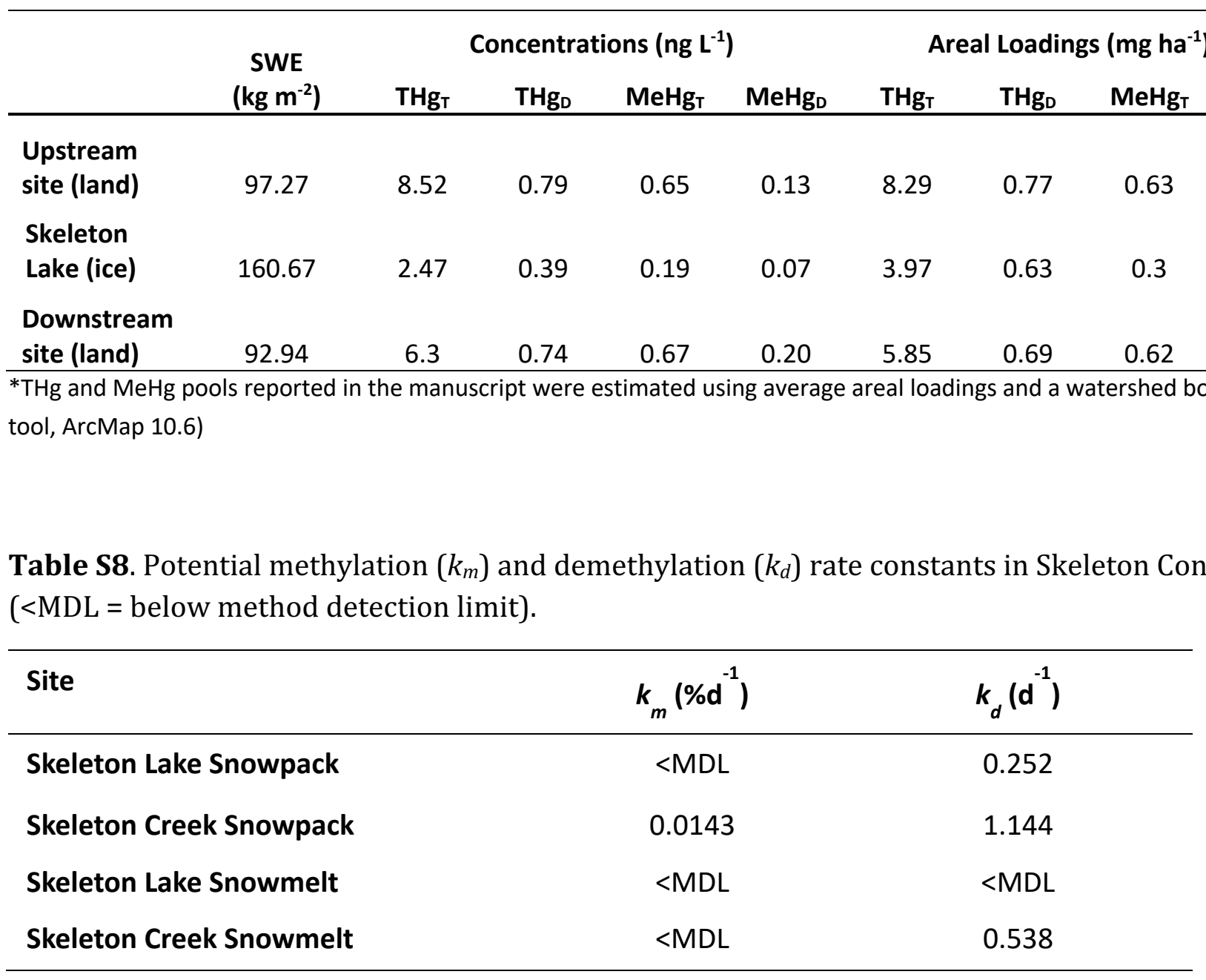


Table S9. Ranges of THg (ng L-1 , ng g-1 or \%), MeHg (ng L-1 , ng g-1 or \%), and Hg methylation/demethylation constants (\% d-1 or $\mathrm{d}^{-1}$ ) in all media sampled within the Skeleton Continuum. Table shows ranges of all data collected for that media. $\mathrm{n} / \mathrm{a}=\mathrm{data}$ not available. $<\mathrm{MDL}=$ below method detection limit, values reported in main body of text.

\begin{tabular}{|c|c|c|c|c|c|c|c|c|c|}
\hline Site & $\begin{array}{c}\mathrm{THg}_{\mathrm{T}} \\
\left(\mathrm{ng} \mathrm{L}^{-1} \text { or }\right. \\
\left.\mathrm{ng} \mathrm{g}^{-1}\right)^{*}\end{array}$ & $\begin{array}{l}\text { THgD } \\
\left(\mathrm{ng} \mathrm{L}^{-1}\right)\end{array}$ & $\begin{array}{c}\text { \%THg } \\
\text { dissolved }\end{array}$ & $\begin{array}{l}\mathrm{MeHg}_{\mathrm{T}} \\
\left(\mathrm{ng} \mathrm{L}^{-1} \text { or }\right. \\
\left.\mathrm{ng} \mathrm{g}^{-1}\right)^{*}\end{array}$ & $\begin{array}{l}\text { MeHgo } \\
\text { (ng L-1) }\end{array}$ & $\begin{array}{l}\text { \%MeHg } \\
\text { dissolved }\end{array}$ & \%MeHg & $\begin{array}{c}k_{m} \\
\left(\% d^{-1}\right)\end{array}$ & $\begin{array}{c}k_{d} \\
\left(d^{-1}\right)\end{array}$ \\
\hline Snowpack $(n=3)$ & $2.47-8.52$ & $0.39-0.79$ & $9-16$ & $0.19-0.67$ & $0.07-0.20$ & $21-39$ & $8-11$ & $\begin{array}{c}<M D L- \\
0.143\end{array}$ & $\begin{array}{c}0.25- \\
1.14\end{array}$ \\
\hline Snowmelt $(n=2)$ & 4.01-4.16 & 2.17 & $52-53$ & $0.18-0.67$ & $0.07-0.20$ & $62-66$ & 3 & $\begin{array}{l}<M D L- \\
0.0009\end{array}$ & $0-0.54$ \\
\hline $\begin{array}{l}\text { Seep Water } \\
(n=10)\end{array}$ & $0.37-1.29$ & $0.35-0.69$ & $53-100$ & $<.01-0.04$ & $<0.01$ & $21-100$ & $0.3-10$ & $\mathrm{n} / \mathrm{a}$ & $\mathrm{n} / \mathrm{a}$ \\
\hline $\begin{array}{l}\text { Skeleton Lake } \\
\text { Water Column } \\
\text { (Spring) }(n=8)\end{array}$ & $0.94-1.34$ & $0.83-1.02$ & $74-100$ & $0.41-0.72$ & $0.36-0.65$ & $81-98$ & $43-57$ & $<M D L$ & $\begin{array}{c}<M D L- \\
0.043 \\
(\% d-1)\end{array}$ \\
\hline $\begin{array}{l}\text { Skeleton } \\
\text { Lake/Pond Water } \\
\text { Column } \\
\text { (Summer) }(n=15)\end{array}$ & $0.52-1.10$ & $0.35-1.10$ & $46-100$ & 0.04-0.09 & $0.03-0.06$ & $40-84$ & $7-18$ & $<M D L$ & $<M D L$ \\
\hline $\begin{array}{l}\text { Zooplankton } \\
\text { (Spring) }(n=2)\end{array}$ & $46-59$ & $\mathrm{n} / \mathrm{a}$ & $\mathrm{n} / \mathrm{a}$ & $10-19$ & $\mathrm{n} / \mathrm{a}$ & $\mathrm{n} / \mathrm{a}$ & $22-32$ & $\mathrm{n} / \mathrm{a}$ & $\mathrm{n} / \mathrm{a}$ \\
\hline $\begin{array}{l}\text { Zooplankton } \\
\text { (Summer) }(n=8)\end{array}$ & $90-123$ & $\mathrm{n} / \mathrm{a}$ & $\mathrm{n} / \mathrm{a}$ & $43-99$ & $\mathrm{n} / \mathrm{a}$ & $\mathrm{n} / \mathrm{a}$ & $37-84$ & $\mathrm{n} / \mathrm{a}$ & $\mathrm{n} / \mathrm{a}$ \\
\hline
\end{tabular}




\begin{tabular}{|c|c|c|c|c|c|c|c|c|c|}
\hline $\begin{array}{l}\text { Skeleton Lake } \\
\text { Sediment } \\
\text { (Spring) }(n=3)\end{array}$ & $8.26-39.53$ & $n / a$ & $n / a$ & $0.05-0.15$ & $n / a$ & $n / a$ & $0.1-0.4$ & $\begin{array}{c}0.64- \\
1.12\end{array}$ & $\begin{array}{l}3.02- \\
7.77\end{array}$ \\
\hline $\begin{array}{l}\text { Skeleton Lake } \\
\text { Sediment } \\
\text { (Summer) }(n=4)\end{array}$ & $8.78-53.75$ & $n / a$ & $n / a$ & $0.30-1.05$ & $\mathrm{n} / \mathrm{a}$ & $\mathrm{n} / \mathrm{a}$ & $1-12$ & $\begin{array}{l}1.26- \\
8.65\end{array}$ & $n / a$ \\
\hline $\begin{array}{l}\text { Pond Sediment } \\
\text { (Summer) }(n=4)\end{array}$ & $6.44-15.61$ & $n / a$ & $n / a$ & $0.17-4.36$ & $\mathrm{n} / \mathrm{a}$ & $\mathrm{n} / \mathrm{a}$ & $2-28$ & $\begin{array}{l}4.75- \\
9.19\end{array}$ & $n / a$ \\
\hline $\begin{array}{l}\text { Post Pond Water } \\
(n=7)\end{array}$ & $0.41-1.43$ & $0.40-0.60$ & $31-100$ & $0.11-0.49$ & $0.09-0.18$ & $29-88$ & $17-51$ & $\mathrm{n} / \mathrm{a}$ & $n / a$ \\
\hline $\begin{array}{l}\text { Wetland Soil } \\
(n=16-82)\end{array}$ & $2.05-71.19$ & $n / a$ & $n / a$ & $0.11-6.71$ & $\mathrm{n} / \mathrm{a}$ & $n / a$ & 0.3-17 & $\begin{array}{l}0.16- \\
4.98\end{array}$ & $\begin{array}{l}0.08- \\
10.83\end{array}$ \\
\hline $\begin{array}{l}\text { Post Wetland } \\
\text { Water }(n=5)\end{array}$ & $0.67-1.11$ & 0.63-0.95 & $85-99$ & $0.02-0.26$ & $0.01-0.03$ & $4-100$ & $2-23$ & $\mathrm{n} / \mathrm{a}$ & $n / a$ \\
\hline $\begin{array}{l}\text { Skeleton Creek } \\
\text { Water }(n=5)\end{array}$ & $0.76-1.23$ & $0.75-1.18$ & $88-99$ & $0.02-0.03$ & $0.02-0.03$ & $77-100$ & $2-3$ & $\mathrm{n} / \mathrm{a}$ & $n / a$ \\
\hline
\end{tabular}

* Soil, sediment, and zooplankton concentrations are measured in $\mathrm{ng} \mathrm{g}^{-1}$ dry weight, all other samples are measured in $\mathrm{ng} \mathrm{L}^{-1}$ 


\section{REFERENCES}

(1) Lehnherr, I.; St. Louis, V. L.; Emmerton, C. A.; Barker, J. D.; Kirk, J. L. Methylmercury Cycling in High Arctic Wetland Ponds: Sources and Sinks. Environ. Sci. Technol. 2012, 46, 10514-10522.

(2) Lehnherr, I.; St. Louis, V. L.; Kirk, J. L. Methylmercury Cycling in High Arctic Wetland Ponds: Controls on Sedimentary Production. Environ. Sci. Technol. 2012, No. 46, 10523-10531.

(3) St Pierre, K. A.; St. Louis, V. L.; Lehnherr, I.; Gardner, A. S.; Serbu, J. A.; Mortimer, C. A.; Muir, D. C. G.; Wiklund, J. A.; Lemire, D.; Szostek, L.; Talbot, C. Drivers of Mercury Cycling in the Rapidly Changing Glacierized Watershed of the High Arctic's Largest Lake by Volume (Lake Hazen, Nunavut, Canada). Environ. Sci. Technol. 2019, 53 (3), 1175-1185.

(4) Lehnherr, I.; St. Louis, V. L.; Hintelmann, H.; Kirk, J. L. Methylation of Inorganic Mercury in Polar Marine Waters. Nat. Geosci. 2011, 4 (5), 298-302.

(5) Willis, C. E.; Kirk, J. L.; St. Louis, V. L.; Lehnherr, I.; Ariya, P. A.; Rangel-alvarado, R. B. Sources of Methylmercury to Snowpacks of the Alberta Oil Sands Region: A Study of In Situ Methylation and Particulates. Environ. Sci. Technol. 2018, 52, 531-540.

(6) Hintelmann, H.; Evans, R. D. Application of Stable Isotopes in Environmental Tracer Studies - Measurement of Monomethylmercury (CH3Hg+) by Isotope Dilution ICPMS and Detection of Species Transformation. Fresenius. J. Anal. Chem. 1997, 358 (3), 378-385.

(7) US Environmental Protection Agency. Method 1630, Methyl Mercury in Water by Distillation, Aqueous Ethylation, Purge and Trap, and Cold Vapor Atomic Fluorescence Spectrometry Engineering and Analysis Division ( 4303 ). 1998.

(8) US Environmental Protection Agency. Method 1631, Revision E: Mercury in Water by Oxidation, Purge and Trap, and Cold Vapor Atomic Fluorescence Spectrometry. 2002.

(9) Hintelmann, H.; Ogrinc, N. Determination of Stable Mercury Isotopes by ICP/MS and Their Application in Environmental Studies. Am. Chem. Soc. 2003, 321-338.

(10) US Environmental Protection Agency. Method 7473, Mercury in Solids and Solutions by Thermal Decomposition, Amalgamation, and Atomic Absorption Specrtophotometry SW-846. 2007.

(11) Lehnherr, I.; St. Louis, V. L. Importance of Ultraviolet Radiation in the Photodemethylation of Methylmercury in Freshwater Ecosystems. Environ. Sci. Technol. 2009, 43 (15), 5692-5698. https://doi.org/10.1021/es9002923. 